\title{
sciendo
}

DOI: $10.2478 /$ jolace-2021-0019

\section{Europe as an extended Greece: Travelogues by Karl Kerényi and Gábor Devecseri}

\author{
Anikó Polgár \\ J. Selye University in Komárno, Slovakia \\ polgara@ujs.sk
}

\begin{abstract}
This study is dealing with the travel notes and diaries in Hungarian and German from the 1950s and 1960s. The two examined authors are Karl (Károly) Kerényi (1897-1973) and Gábor Devecseri (1917-1971). Kerényi's travel notes and diaries reveal the thoughts of a very wide-ranging scholar. Devecseri's volume Crickets of Epidaurus, Sing (Epidauroszi tücskök, szóljatok) is actually a collection, condensed into the history of four trips: three to Greece and one to Italy. The present study examines the characteristics of these two perspectives, namely, the Western vs. the Eastern, the classic scholar's vs. the scholarly poet's using the contexts of travelogues and cultural memory as a point of departure. While for Kerényi, travel is a natural way of life, Devecseri travels and uses his idea based on his reading experiences as starting points. In the texts of both authors, we are confronted with both the archival and the current way of life of cultural memory.
\end{abstract}

Key words: Hungarian Literature, Travelogues, Greece, Cultural Memory, Karl Kerényi, Gábor Devecseri

\section{Introduction}

The present study aims to link the analysis of travel literature with the issues of myth, Antiquity, and emigration, analyzing travelogues, travel notes and diaries in Hungarian and German from the 1950s and 1960s. They mainly concern Greece and Italy, occasionally other parts of Europe, but in the latter case too they are strongly linked to the antique heritage of European culture. In the course of the analysis, the comparative method prevails although there are many parallels between the two examined authors, Karl (Károly) Kerényi (18971973) and Gábor Devecseri (1917-1971), the differences in point of view and representation are also significant. The teacher-student relationship between them is decisive, but there is also a significant difference in their relationship to Antiquity from the scholar's vs. the fiction writer's points of view. Kerényi was a broad-minded scholar who regarded the linguistic formulation of his scholarly works as exceptionally important and who also saw parallels between Antiquity and contemporary processes, whereas Devecseri was a poet and translator of classical education, essayist, and Hungarian translator of Homer, among others. Travelogues and travel notes and diaries, however, are works that can be measured by literary standards in both of them, and they stem from a similar interest in cultural history.

The most striking is the difference between belonging to the Western and Eastern blocs, from the point of view of emigration and staying at home, the use of the mother tongue and the foreign language learned and made one's own. Kerényi lived in Switzerland from 1943 until his death, and while he used both Hungarian and German in his writings in Hungary, he got more and more detached from his mother tongue after the war, and his notes in the 1950s and 1960s are in German. From a young age, Kerényi traveled regularly to his research sites, 
Greece and Italy, from the 1920s; for his essays and research papers on Antiquity, he found inspiration in the sight of landscapes and antique artefacts and archeological finds.

For Devecseri, the journey and the encounter with the mementos of Antiquity did not become as natural as for his teacher: although he translated classic literature beginning with the 1930s, he visited Greece only in 1960, confronting the reality with phenomena he knew from books, and he looked around not only through the eyes of the literary translator and classical philologist, but also through the eyes of a traveler temporarily moving west from the socialist world.

The present study examines the characteristics of these two perspectives, namely, the Western vs. the Eastern, the classic scholar's vs. the scholarly poet's (poeta doctus) using the contexts of travelogues and cultural memory as a point of departure.

\section{Myth, travel and cultural memory}

Myth and cultural memory play a particularly important role in travelogues looking for traces of Antiquity. According to an essay by Karl Kerényi, mythology is an ancient, traditional material, which is manifested in further transformable narratives ( $\mu$ vo $\lambda$ ó $\eta \mu \alpha)$ about gods and heroes (Kerényi, 1939, p. 12-13). An important element is the mobility and live nature of the material: Kerényi emphasizes that a myth is a living reality, a way of thinking and expressing for the bearers of mythology (1939, p. 16). Linking the present and the myth is also an essential element of Jan Assman's theory of cultural memory. Cultural memory also makes it possible for mythology and later ages to meet, for its terrain is mythical prehistory: according to Assmann's definition, "[m]yth is foundational history that is narrated in order to illuminate the present from the standpoint of its origins" (2011, p. 38).

In the travelogueues, in fact, the archival and actual manifestations of cultural memory meet: the archival is represented in artefacts, preserved in museums or in classical texts, while the actual is manifested through confrontation with the experience of reality (Assmann, 1988, p. 11). Knowledge based on readings and cultural knowledge is confronted with an authentic medium (or one believed to be authentic), and the relationship of the present with the past which is represented in buildings, monuments, cities or landscapes, that is, with the topographic manifestations of cultural memory - comes to the fore (Assmann, 1988, p. 11). The museum, as Assmann notes (1999, p. 31), can be a place of concealment („ein Ort der Latenz"), as it collects objects that are disconnected from their function, but at the same time it can confront the visitor with the special, which also feels as one's own.

The travelogue is also related to remembrance, as one of its aims is to capture experiences and otherwise forgettable details. The traveler can transform the experience into a memory by relying on the preserving function of the myth (Jagow, 2000, p. 7).

Starting from Karl Kerényi's conception of myth and Assmann's theory of cultural memory, several sub-aspects arise at the connection points between myth, cultural memory and travel literature, e.g. problems of documentation and documentability, the relationship between people and Antiquity, or the cultural message of the archaisms of language. Building on the theoretical foundations outlined above, the travelogues of Karl Kerényi and Gábor Devecseri will be approached from the perspectives of the role of travel: how it becomes a way of life, how emigration is mythicized, how myth and artistic capture contradict each other, how mythical pseudo-claims are made, how the present and the mythical past meet in humorous and/or ironic ways, memory, language, and identity are interconnected. 


\section{The mythicization of travel and emigré existence in the travel diaries of Karl Kerényi}

In one of Kerényi's best-known essays (Kerényi, 1984), further developing the dualism of Nietzsche's Apollonian-Dionysian worldview, he highlighted a third spiritual reality, the Hermesian, with which, judging by his writings, his spiritual constitution can also be related. Kerényi distinguishes between the wanderer and the traveler. According to him, the wanderer takes possession of another piece of land with each step, while the traveler's condition, on the other hand, is hovering (Kerényi, 1984, p. 18-19). The world of trails belongs to the traveler, be they land or sea trails (Kerényi, 1984, p. 20). This characterization of the traveler protected by Hermes can even be read as a self-confession. In a travel note, Kerényi recalls a friend's reflection on the German Wanderer and his alleged Hungarian counterpart, the fugitive: Kerényi emphasizes that he does not feel like a fugitive, he is more of a Hermesian traveler (Kerényi, 1954, p. 65).

Kerényi's travel notes and diaries (Kerényi, 1954 and Kerényi, 1969), written with the quality of fiction, reveal the thoughts of a very wide-ranging, versatile scholar. In the preface to his travelogue published in Zurich in 1954, Kerényi states that traveling has become a way of life for him: this came not only from his natural inclinations, but also from external compulsions (Kerényi, 1954, p. 9-14). Initially, he fled from the national confinement of the 1930's Hungary to the locations of his research, primarily to Greece and Italy. In Hungary in the 1930s, ${ }^{1}$ Kerényi stood diametrically opposed to the program of classical philology exploited for national purposes, representing the view that the study of Antiquity cannot be nationalist because the legacy it handled is a common property of European culture (Szilágyi, $2005,506)$. Due to this, Kerényi did not get a place among the official leaders of Hungarian studies of the Antiquity (he did not continue to edit Egyetemes Philológiai Közlöny, and, as a teacher, he was moved from Budapest, the center, to the university in Pécs). In his travel notes, which contained also his memories, he refers to how he commuted between Budapest and Pécs in the early 1930s, highlighting the southern nature of the landscape around Pécs, which strengthened his attachment to Greece. Kerényi evaluates his last years in Hungary as a preparation for a travel life, and names two tendencies that have led to his departure from the middle class perception of travel: the limitations of the national horizon of learning, and a longing for endangered European values.

When he left Hungary permanently in 1947, following conscious attempts to drive him away, he felt exiled and never again returned to the land of Hungary, suffering under Soviet occupation (Szilágyi, 2011, p. 311). Apart from a brief appointment in Basel, he did not hold a university teaching position during the time of his emigration, instead living on grants, giving lectures, and writing, and this way of life was accompanied by constant travel. According to János György Szilágyi, the traveling Kerényi was only interested in ancient landscapes: "'why should I go to America if there is another road or path in Greece that I don't know', he once told an archaeologist friend" (Szilágyi, 2011, p. 312). Kerényi's travel diaries contradict this somewhat, proving that he turned to many other landscapes with interest, although only within Europe (the America-Greece juxtaposition thus indirectly means the juxtaposition of America and Europe).

Kerényi saw the extension of Greece throughout Europe: "Europe, an extended Greece, the land of the gods ("Europa, ein erweitertes Griechenland, Götterland") he wrote in the first volume of his travelogues (Kerényi, 1954, p. 10). He saw the world around him in a Greek

1 For more on the role of Hungarian research into the Antiquity in the 1930s, see Szilágyi (2005, pp. 489-518). 
fashion, even when he happened to be not in Greece. He also distinguished his own phases of life through his trips to Greece: for the period of World War II for him mean the years spent away from Greece, and the first Etruscan journey after the war was intended to make up for the missed trips to Greece (Kerényi, 1954, p. 10). At the time of his return to Ascona, he perceived the landscape as a Greek mythological landscape. The author of a diary entry dated November 11,1954, sees the fruit of the tree in front of the house as the apples of the Hesperis (Kerényi, 1969, p. 76).

He notes of bulls seen at a fair in Assisi that their necks seem to be shaped based on archaic vase images (Kerényi, 1954, p. 17). This is a way of seeing and showing at the same time, with the conscious functioning of fantasy and the conscious evocation of memories playing a role, usually supported by some visual resemblance as well. This is evidenced by an entry in which Kerényi reports that when he walked the Palatine Hill one evening, he tried, with the power of memory, to make himself walk in Athens and Rome at the same time, for the picturesqueness of the Palatine evening view can be measured by the plasticity of the view from the Acropolis (Kerényi, 1954, p. 72).

The Greek experience permeates everything in such a way that parallels appear all the time: he notices traces of Greece everywhere, not only when walking in Europe, but memories of experiences from other parts of Europe with a classical-philological sensibility come to him also in Greece. When he sees the island of Skyros from the deck of the ship Ionion in the light of stars at one o'clock at night, he remembers the symbolist images of Arnold Böcklin seen in Basel (Kerényi, 1954, p. 100). During his trip to France, he finds it no wonder that the French do not have a desire for Greece, as they also have a glowing Greece („Griechenland im Licht") at home (Kerényi, 1969, p. 59). It is true, he adds, that the two are not the same, but it is only a step away from here, a prelude to it („eine Vorstufe“, Kerényi, 1969, p. 59).

Emigration itself appears as a mythical theme to Kerényi: the myth of Heracles with the deer of Ceryneia takes him in his reflections to the ancient Hungarian myth of the miracle stag, the subject of an earlier paper of his, first published in Hungarian. He sees emigration to be the essence of the miracle stag (Kerényi, 1969, p. 166). In emigration, he feels the positive energies of meeting the other rather than the alarming alienation. However, before finding oneself at home with the other, the emigrant goes through death: his past is erased, his previous self is replaced, and his former, previously primary language is worn out of use. Finding oneself at home with the other is like being freed from death, the only possibility to survive.

The appearance of a something influencing one's mood, or of a memory, increases the feeling of being at home in the emigrant. Natural phenomena, plants and animals often remind him of his childhood, e.g. of his grandfather, who loved peacocks (Kerényi, 1969, p. 184). The memory of a Hungarian landscape is sometimes so intertwined with the linguistic expression that an element is also included in Hungarian within German sentences. Kerényi also tells in Hungarian words embedded in the German text how his grandfather baked large amounts of bread (12 loaves of 3 to 5 kilos each) in Gurahonc, which he sold to Romanians coming down from the mountains (Kerényi, 1969, p. 277).

According to self-analytical and recollectionary entries, his grandfather's closeness to nature and the earth helped to shape the sensual philology (sinnliche Philologie) that became the basis of Kerényi's scholarly thinking (Kerényi, 1969, p. 278). Its essence is that concrete, tangible reality is a prerequisite for understanding spiritual nuances. He misses this from the English translation of the second part of his Greek mythology when reading the proofs. He complains that The Heroes contains a number of mistranslations, e.g. instead of the Saumweg 
(mountain trail) in Isthmos, the English translation has a swampy path (Kerényi, 1969, p. 283). According to Kerényi, the translator is blind to both concrete details and intellectual nuances: „Blind für das Konkrete - blind aber auch für die geistige Nuance.” (Kerényi, 1969, p. 283). One needs to find an internal language that matches the topic, which can be achieved by letting the classic material itself speak.

While traveling, it is usual to move away from the usual framework of life, in fact, by being the road almost constantly, no basic structure is formed, which can be considered as a starting point at home, in relation to which the trip would mean a move and a change. Travel notes taken at different locations are held together by a German language which he designed for his own purposes, and changes of language spring symptomatically from the basic pattern, for which the change of frame is not enough but which require emotional agitation, as well. Phrases, sentences, and paragraphs in other languages that are sometimes included in the basic German text are mostly derived from memories, the context of his travels, or readings. Kerényi occasionally switches languages within a paragraph (Kerényi, 1969, p. 342). This multilingualism was obviously part of the editorial concept, the German translation of the foreign language parts is included in the notes at the end of the volume.

In addition to the German language, Latin and Greek, which were fundamentally related to the subject of his writings, were also deeply seated in him. Although these are dead languages, he still felt that they were alive in him, more alive than in the colleagues of other philologists (Kerényi, 1954, p. 94). The same vitality is evident in the perspective of his works, most notably in Greek mythology, in which he tells stories from an insider's perspective. According to Kerényi, divine and human are represented in Greek mythology without being tied to time. He distinguishes between the periodic time of myth, the straightforward time of world history, and the timelessness of Greek mythology.

Mythology is palpably present not only in archaeological finds but also in contemporary Greek everyday life. This is presented, for instance, in a story heard from a Chios fisherman about a little boy, left alone at sea, who escaped in an unexpected way. The boy was left alone on a barge by men fleeing the storm, trying to swim ashore but drowning, while, as the storm subsided, the little boy escaped alive. In the story, Kerényi sees a mythological image of an ancient child god floating in the sea (Kerényi, 1954, p. 116).

The notes are continuously related to Kerényi's previous papers or studies he worked on the way. Traveling may be a confrontation between the subject of his readings and reality, but the confrontation with reality may also provide subsequent confirmation of the intuitions on which a Kerényi essay written earlier is based. For instance, on the island of Samotraké, he remembers the preface to his study Aegean Feast (Az égei ünnep) on Faust's scene in the Aegean Sea. The study was written in Hungary, on the shores of Lake Balaton in 1940, and now he finds on the shores of the sea that what he wrote about the atmosphere of the sea (Meeresstimmung) holds, and he does not have to change it afterwards (Kerényi, 1954, p. 107).

Reading older works also contributes to the prolongation of one's own memory, which is why Kerényi liked to read older guidebooks during his travels. In Greece, reading a travel diary written in 1822 (Tagebuch einer Reise nach Morea im Jahre 1822), he feels as if his own memories date back a hundred years earlier (Kerényi, 1954, p. 31). Readings in different languages and the alternate use of languages seem to mean the expansion of the boundaries of his self. Kerényi's horizon - which cannot be called narrow even at the beginning - expands even further. 


\section{Encounters of the present and the mythical past in Gábor Devecseri's travelogues}

The perspective of Devecseri's travelogueues is rooted in classicism. According to the basic scheme of the classicists' travelogueues, the journey is preceded by a dream, an image conveyed by tradition: the traveler constantly compares this image and his real experiences, and by the end of the journey the preliminary image is either confirmed or transformed, and the various impressions form a new picture (Grimm, 2005, p. 155). While the classicist carried away by his ideals usually does not convey their individual experiences but relies primarily on cultural memory and on patterns fixed by tradition (Grimm, 2005, p. 176), in Devecseri's work, using neoclassicism as the point of departure, the two aspects are balanced.

His volume Crickets of Epidaurus, Sing (Epidauroszi tücskök, szóljatok) is actually a collection, condensed into the history of four trips: three to Greece $(1960,1963,1967-68)$ and one to Italy (1965). Devecseri had already traveled extensively earlier, in the 1950s, as a favorite of the Communist system, but these trips were mainly to the countries of the socialist bloc, with no deep cultural and historical interest behind them as in the case of later trips to Greece and Italy.

The title of the first part of Crickets of Epidaurus, Sing, similarly to the previous, 1961 volume, is Homeric Journey (Homéroszi utazás), but it is not exactly the same as the material in the previous volume. ${ }^{2}$ The text is reduced at several points, and the new publication also provides an opportunity for conceptual corrections. Ideological emphases are subtly shifted by fewer elements referring to Devecseri's role in the 1950s.

The second part of the volume Crickets of Epidaurus, Sing is a description of the second trip to Greece, titled Odysseus's Ship (Odüsszeusz hajója). The second trip took place two and a half years after the first, beginning on April 19, 1963. János György Szilágyi, the then head of the Antiquities Department of the Budapest Museum of Fine Arts, took part in the trip, funded by Corvina Publishing House, as an expert of the art history of Antiquity, in order to create a mixed media work (Szilágyi, 2018, pp. 171-172). The plan was to traverse a mythical literary route, in order to translate fiction into reality. Although the implementation encountered constant obstacles, the fictitious path and the Odysseian framework determined their way of seeing, the selection and judgment of what was seen. The three travelers wanted to explore the landscapes of the Odysseia: Károly Gink, the photographer, took the photos, with which Devecseri planned to associate the details of his own translation of Odysseia, but in the end, going beyond the original plan, a prose travelogue enriched with poems was written. Gink's photos of Greece can be seen not only as illustrations of Devecseri's travelogue (Devecseri, 1969), but as also in a smaller album entitled Ithaca!, in which the photos are accompanied by extracts of Devecseri's poems and poetry translations, in line with the original design (Gink \& Devecseri, 1969).

Official trips at the time inherently meant that travelers were under constant observation. Devecseri wrote openly about being tailed by two agents in Greece. The issue first emerges when describing the Ithaca cruise, where the travelers noticed that the two men with mustaches were always on board at the same time when they were, and as soon as they went inside, they were followed there too (Devecseri, 1969, p. 220). He also referred to an agent observing them in the Islands in September (Szigetek szeptemberben) section of his third trip to Greece, writing about an Athens feast with friends that lasted so long that the lone gentleman at the table next to theirs had to have lunch twice in order to stay there to watch them (Devecseri, 1969, p. 373).

2 I have written about Homéroszi utazás (1961) in an earlier paper (Polgár, 2019). 
Due to the nature of the trip (an assignment from his publisher), he could not engage in selfforgetful looking, as the collection of materials was primary, and Devecseri called himself and his companions wanderers with a condensed itinerary („sürített útitervű vándorok“, Devecseri, 1969, p. 197). It was not the moment that mattered but that he capture it: only later retrospection and remembering could give real joy and a good feeling. Already while traveling, the travelers seemed to be part of a film that can be watched afterwards, and Devecseri talked about the speed of film spinning (Devecseri, 1969, p. 120).

The difficulties of documentation are central to the Odysseus's Ship section. There are always obstacles in the way of Gink's photography, mostly at the mercy of museum directors or room guards regarding whether tripod photography was allowed, but the sun could also be an obstacle. Ironic remarks about documentation are common in the text. As it was not selfserving, professional equipment was essential, and only proper communication could provide the needed permission. The means of communication that help travelers also come from the past. Cultural memory is represented not only in the landscape, in archeological finds, in works of art, but also in the archaisms of the language unconsciously used by people. During the journey, the words of Ancient Greek were turned into Contemporary Greek, like a cleansed archaeological find supplemented with modern materials, not merely carriers of cultural memory, but means of use that make actions flexible. With this method, the harsh attitude experienced from borderguards and museum guards can be resolved. In today's Greek language, Devecseri observed the elements of Ancient Greek known from the classics, and saw the collision of two time planes and messages from the past. For example, the phrase Mé trekhete! warns heroes not to run from the enemy in Homer, but today it warns drivers to beware of speeding (Devecseri, 1961, p. 12). Linguistic messages that erupt from the depths of cultural memory form a connection between the present and the archaic past, but these messages can necessarily only be decoded by the initiates. Of the two planes, the archaic is primary, and Devecseri, as a translator of ancient Greek literature, is an intimate connoisseur of it, so for him the recognition of New Greek words is like deciphering a message written in code.

A traveler with a classical philological education clings to the words of Ancient Greek, modernizes his words from it, and, similarly to this linguistic experience, is able to make foreign cities feel like home by discovering elements of the Antiquity in them. It is reflected in antique artefacts, archaeological finds preserved in museums, in texts of classical literature, or in Ancient Greek itself, in the archival mode of existence of cultural memory, but elements of the same language used in New Greek pronunciation, adapted to the syntax of a new language, show the current existence of cultural memory. ${ }^{3}$

The figure of the grim museum guard becomes a topos, popping up at several points in the text, not only hindering the documentation, but also confronting the visitor immersed in the timelessness of the work of art with the finiteness of time. The museum, full of antique artifacts, becomes a metaphor for the fullness of life, while the closing hour, depriving one of the enjoyment of art and pleasures, that of the foreshadowing of death (Devecseri, 1969, p. 370).

The Odysseus's Ship section of the volume is the most witty part of the travelogueue, the humor is strongest in this part, and the travelers themselves laugh a lot. The source of humor is often the juxtaposition of contemporary and mythical events. After a truck smashes into Károly Gink's parked car, the travelers are forced to fight an insurance company. Papakiriaku,

3 On the archival and actual mode of existence of cultural memory (see Assmann, 1988, p. 13). 
a Greek lawyer who comes on scene to help them, defends them as Aias in the Iliad defended Teucros with his shield (Devecseri, 1969, p. 159). We witness a similar battle scene in the museum in Thessaloniki, where two art historians (György János Szilágyi and the museum director who allowed photography after the duel) fight each other, while, as in the Iliad, Galukos and Diomedes exchange their weapons, special prints of publications (Devecseri, 1969, p. 123).

The ironic interplay of mythical and contemporary planes also helps to expose the pseudomyth of the average days of the trip. Due to the condensed itinerary and lack of money, it is a problem to solve meals, the travelers have to hurry all the time, there is no time for delays. All of this, contrasted with the serenity of the Homeric heroes, does not seem so frustrating. An important element of the travelogue technique is the presentation of these parallels: the author often jumps from depicting their own meal to describing a Homeric meal (Devecseri, 1969, p. 188).

While Homeric Journey is dominated by the voice of classicist-rooted rapture, Odysseus's Ship treats the myth with humor, showing the Antiquity together with its flaws to be lovable. Maintaining mythical consciousness requires not exact facts but imagination. In the Taygetos, where the travelers feel like Spartan babies among the great depths and sudden bends (Devecseri, 1969, p. 196), they begin to discuss where the house of Diokles - with whom Telemachus rested in Pherae, on his way from Pylos to Sparta - could have stood. Mythical sites can also be created through ironic pseudo-claims: János György Szilágyi randomly points to a rocky hill in the middle of the road, and with this the mythical mystery of Diokles's house is solved through pseudo-claim.

Traveling is not only a showcase of mythical memory but also helps to explore the hitherto hidden layers of individual memory. Mythical sites are often identified with Hungarian sites that appear in memory, and many personal memories and reading experiences related to writers also arise. For instance, ideas of Frigyes Karinthy, the literary master who inspired Devecseri and fundamentally defined his prose style, make several appearances.

Cultural memory is built from cultural panels, while the presentation of historical reality is not the goal. A good example of this is the Agamemnon mask that can be seen in the National Archaeological Museum in Athens which did not actually belong to the mythical Agamemnon (Devecseri, 1961, p. 17). The mask connects two time planes, with a distant existence flowing into an actual one (Kerényi, 1995, p. 90). The Agamemnon mask evokes several distant existences from the past at once: the time of the real owner of the death mask, that of the mythical Agamemnon, and of Homer singing his fate, and finally that of Schliemann, who discovered and named the mask. The three basic forms of cultural memory (linguistic, ritual, and pictorial) are, according to Assmann (1988, p. 14), reminiscent of the trinity of Greek mysteries (legomenon, dromenon, deiknymenon). The traveler's encounter with the Agamemnon mask also evokes all three basic forms. In Devecseri's description, there is clearly a linguistic and pictorial plane (although the projection of these, the Homeric text and the Mycenaean artwork on each other is arbitrary), but the mention of the ritual element, the funeral ceremony, is not left out either. Although the rite in this case is the property of a bygone age, it cannot be transferred to our time, but the artistic and emotional power radiating from the mask illustrates the celebration. According to Karl Kerényi (1995, p. 84-85), the main function of the mask is to make contact between the living and the dead, and one of the necessary functions is scaring. The sight of the Agamemnon mask is also a terrifying 
experience, Devecseri (1961, p. 16) feels life and warmth on it, but also the alarm of death and passing away.

In Crickets of Epidaurus, Sing, we do not only travel in the footsteps of Homer, but also venture back to Devecseri's youthful memories and early stages of immersion in Greek culture, including conversations with Kerényi and readings of his works. As two Kerényi students, Gábor Devecseri and György János Szilágyi, travel together in the central part, it is natural that the memory of Kerényi's pre-war university lectures on Fridays will appear in their conversations (Devecseri, 1969, p. 123). Master and disciple grew cold to each other over time due to both spatial and ideological distance. Kerényi, who visited Greece several times in the 1960s, independently of Devecseri and his co-travelers, knew about Szilágyi and Devecseri's joint trip to Greece. In a letter to Szilágyi, he asks about their experiences in Ithaca, inquiring about the current state of the island (Komoróczy, 2018, p. 196).

The chapter entitled Interlude (Közjáték) in Devecseri's guidebook describing the Italian journey bears the subtitle Iter Catullianum, referring to Kerényi's preface to Devecseri's first translation volume, the collected poems of Catullus. On the trip to Italy, Devecseri accompanied his wife, opera director Klára Huszár, to the Spoleto music festival organized by Gian Carlo Menotti, while also having some time to meet emigrant acquaintances. In Florence, they meet an old friend of theirs, art historian Péter Meller, a 1956 emigrant who had also attended Kerényi's classes. They traveled from Italy to Switzerland, staying in Ascona with Gyula Háy, and the culmination of the trip was visiting Karl Kerényi. Devecseri was looking for a trace of his youthful experience of Catullus, starting from Kerényi's preface to Catullus, according to which the whole of Italy can be found in Catullus's work. The visit in Ascona with Kerényi is also time travel, and from the few sentences with which Devecseri describes this reunion, it can be felt that Devecseri's admiration does not refer to the present but only to the former times. Devecseri considers the Kerényi he meets in Switzerland too arrogant, the Devecseris see Kerényi's house as conservative and gloomy in contrast to Gyula Háy's modern house, and their aversion is only solved when they imagine themselves on Kútvölgyi út, in Kerényi's old Hungarian home.

\section{Conclusion}

The differences in the travelogues of the two authors are due to differences in their relationship to traveling. While for Kerényi, travel is a natural way of life, Devecseri travels and uses his idea based on his reading experiences as starting points. For Kerényi, travel is part of everyday life, yet his writings do not lack the exoticism of travelogues. Although the need for travel to establish sensual philology was also characteristic of the pre-emigration period, it also stemmed from the external compulsion to make a living in the last decades of his life. The most exciting parts of Devecseri's travelogues show the meeting of contemporary everyday life seen with the eyes of a tourist and the cultural depths made intimate with philological knowledge. For the philologist and translator, the journey is not only reinforcing and confrontational, it also creates a unique, a third, by connecting two planes.

Kerényi's fiction writers' vein is also reflected in his scholarly works and essays of polished style, and these, more important works, are naturally supplemented by travel notes made in the 1950s and 60s, which answer questions of memory, identity, and emigrant existence with references to Antiquity and to the mythical worldview. While Kerényi's notes proceed in a diary-like, chronological manner, recording current moods, Devecseri's text, which mixes poetry with prose, has retrospective narration. Kerényi's diary entries document the events of 
the given period and reveal related ideas. Devecseri compiled his volume from more uniform, consciously structured travel descriptions that also imitated the recurring elements of the Homeric epics.

In the texts of both authors, we are confronted with both the archival and the current way of life of cultural memory, the experience of reality and the mythical layers are projected on top of each other. During the journey, the ability to decode is important for both of them, whether it be objects of the past or archaicism of the language.

\section{References}

Assmann, J. (1988). Kollektives Gedächtnis und kulturelle Identität. In Assmann, J. \& Hölscher, T. (Eds.), Kultur und Gedächtnis (pp. 9-19). Frankfurt: Suhrkamp.

Assmann, J. (1999). Kollektives und kulturelles Gedächtnis. Zur Phänomenologie und Funktion von Gegen-Erinnerung. In Borsdorf, U. \& Grütter, T. (Eds.), Orte der Erinnerung. Denkmal, Gedenkstätte, Museum, (pp. 13-32). Frankfurt, New York: Campus.

Assmann, J. (2011). Cultural Memory and Early Civilization. Writing, Remembrance, and Political Imagination. Cambridge, New York: Cambridge University Press.

Devecseri, G. (1961). Homéroszi utazás. Budapest: Gondolat.

Devecseri, G. (1969). Epidauroszi tücskök, szóljatok. Görögországi útinapló Gink Károly képeivel. Budapest: Kozmosz.

Gink, K. \& Devecseri, G. (1969). Ithaka! Budapest: Magvető.

Grimm, G. E. (2005). „das Beste in der Erinnerung”. Zu Johann Gottfried Herders Italien-Bild. In: M. Kessler, V. Leppin (Eds.), Johann Gottfried Herder: Aspekte seines Lebenswerks (pp. 151-177). Berlin, New York: De Gruyter.

Kerényi, K. (1939). Mi a mitológia? In: Homérosi himnuszok. Herméshez, Pánhoz, Dionysoshoz (pp. 7-35). Budapest: Officina.

Kerényi, K. (1954). Unwillkürliche Kunstreisen. Fahrten in alten Europa 1952-53. Zürich: Rhein-Verlag.

Kerényi, K. (1969). Tage- und Wanderbücher 1953-1960. München-Wien: Langen Müller.

Kerényi, K. (1984). Hermész, a lélekvezető. Az élet férfi eredetének mitologémája. Trans. by Tatár György. Budapest: Európa.

Kerényi, K. (1995). Az égei ünnep. Tanulmányok a 40-es évekből. Trans. by Kocziszky, É. Budapest: Kráter Műhely Egyesület.

Komoróczy, G. (Ed.) (2018). Kerényi Károly és Szilágyi János György levélváltása. Jelenkor, 61(2), 176-200.

Polgár, A. (2019). Mítosz és kulturális emlékezet Devecseri Gábor Homéroszi utazás című művében. In: I. Lanstyák, A. Polgár (Eds.), Forditás, kulturális hibriditás és többnyelvüség a magyar irodalomtudomány és nyelvtudomány kontextusában (pp. 161-176). Bratislava: Univerzita Komenského v Bratislave.

Szilágyi J. Gy. (2005). Szirénzene. Ókortudományi tanulmányok. Budapest: Osiris.

Szilágyi J. Gy. (2011). A tenger fölött. Írások ókori görög és itáliai kultúrákról, Budapest: Gondolat.

Szilágyi J. Gy. (2018). Örvények fölé épülő harmónia I. Tudományban élni. Budapest: Gondolat, Szépmúvészeti Múzeum.

Von Jagow, B. (Ed.) (2000). Topographie der Erinnerung. Mythos im strukturellen Wandel. Würzburg: Königshausen \& Neumann. 


\section{Contact}

doc. Mgr. Anikó Polgár, PhD.

J. Selye University

Faculty of Education

Bratislavská cesta 3322

94501 Komárno

Slovakia

polgara@ujs.sk 